\title{
Value-Based Education: Professional Development vital towards effective integration
}

\author{
Dr. Ranjani Balaji Iyer
}

\begin{abstract}
Value-based education promotes a thought provoking and interactive environment for the students through the values incorporated in the curriculum. It promotes quality education and holistic development of each child for a bright future. Teachers play an important role in helping students imbibe the values. Professional development is vital in integrating values in the classroom. Understanding the principles and aim of values education enable teachers to create effective learning environment for values education. This article suggests steps to construct a value based curriculum towards quality education. This also emphasizes the importance and need for teacher training for better outcome on the topic, and also suggests a plan to prepare teachers as values educators.
\end{abstract}

\section{Need for Value-based Education}

Value based education instills educational and cultural values among students and aims at achieving multi-faceted development of a human being namely intellectual, physical, spiritual, and ethical development. The values incorporated in a value-based curriculum may include cooperation, responsibility, happiness, simplicity, unity, peace, respect, love, tolerance, honesty, humility, and freedom. The main purpose of holistic education is to prepare students to meet the challenges of living as well as academics. Multiple studies have reported that value based education is a holistic approach to students' education, one that provides complete education of body and mind through innovative approaches and critical educational thinking.

Education can be considered as a means to impart general and specific information; teaching skills and most importantly inculcate values. The present system of education is almost wholly geared to the first, a little to the second and only marginally to the third (Burra, 2007). The neglect of ethical values, which should form the substratum of any good education, has led to ineffectual, decadent, empty learning. Burra describes in the article that it is the duty of every society to pass on the values enshrined in its scriptures and philosophical texts to each generation, in order, that the spirit of its culture lives on. This can be achieved only when education is value oriented. Education should be a process of acquiring true knowledge. In planning for good values and objectives, the teacher and student will have to cooperate and work together. The purpose of education is to strengthen character in the younger generation which is an answer to many of the problems that face people today. It can bring about a widespread renewal of individual commitment to an active life of principle and this renewal is imperative. Values like truth, right action, love, peace and non violence include in a balanced way the profound moral insights of the great civilizations.

\section{Linking Value-based education to teachers and teacher training}

In the $21^{\text {st }}$ century, it is vital to recognize that Value-Based education integrated into the school curriculum promotes quality education and positive school environment. Initiatives in schools around the world have stressed upon an all around development of the students by implementing Value-Based Education programs. Yet it is a greatest challenge in education to teach how to imbibe values as it is different from imparting knowledge of mathematics or science.

Teachers help student perceive information and transform it to knowledge and to wisdom. At the same time, they help adolescent to develop love of knowledge and try to transform into a good citizen. More than ever, now our young people need to have compassion, adaptability, moral courage, patience, and increased tolerance. Cavazos (2002) noted that teaching values in our schools is a vital part of preparing children for the inevitable challenge and occasional pain of real-life decision making. In the article the writer believes that teaching values can enhance education. Values can be positive or negative, depending on circumstances, and this author adds that a values-based education is an education in thinking, in weighing and making choices, in exploring consequences, and in working through problems to find which approaches are helpful in reaching positive, healthy solutions. In an attempt to balance academic achievement and character education, schools and teachers must respect the primary role of the parents and family (Cavazos, 2002). Value-based programs help schools and teachers go hand in hand with the parents by working with them and incorporating values to provide the best educational environment possible for their children. 
Today's world is aware of the importance and relevance of value based education. It is sad to note that the teachers today often are "unmindful" of the tremendous responsibility they have but feel contented with covering the curriculum and producing intellectuals rather than humans. Lickona (1993) noted that "Character education is far more complex than teaching math or reading; it requires personal growth as well as skills development. Yet teachers typically receive almost no pre-service or in-service training in the moral aspects of their craft. Many teachers do not feel comfortable or competent in the values domain. (p. 11)" The teachers are trained and qualified to teach disciplines such as mathematics but are rarely trained to teach values which is usually a very challenging thing to do. This may also be because value education does not form a separate subject of study or examination at any stage of the curriculum. Irrespective of why many training workshops are not available for the educators to imbibe values education, there is a strong need for training teachers in the topic for better outcome. The question that arises is 'Are teachers trained to implement such curriculum?' So, the question of how well the teachers know to impart such knowledge or be effective in promoting effective learning in values education needs to be answered.

\section{Importance of teacher training towards a goal of high quality education}

Values are essential building blocks on which an education for a humanistic and international society must be built on. This boosts self esteem both personal and cultural; promote respect and tolerance for others as individuals and as members of ethnic/cultural groups; and creates a sense of belonging. Value based education promotes a secure physical, emotional and political locus within society; a sense of responsibility in relation to social, political, economic, cultural and environmental factors, an appreciation of the importance of learning (Sanyal, 2000). This approach to education can probe a well-rounded development and help students aim the highest (Eidle, 1993).

'Practice what you preach' is a saying that is very apt for teachers when it comes to values education. Teachers need to be able to imbibe values in their attitude and in action to be able to bring them into their classrooms. Narvaez and Lapsley (2008) looked at education as a value-infused enterprise and addressed the question of how to train teachers for positive character formation. They noted that teachers implicitly impart values when they select and exclude topics; when they insist on correct answers; when they encourage students to seek the truth of the matter; when they establish classroom routines, form groups, enforce discipline, encourage excellence.

\section{Preparing teachers as 'Values Educators' and the $21^{\text {st }}$ century value education schools}

Confucius has outlined the ethics of teaching in three beautiful words. "Ren - means an act of utmost love. Yi - refers to moral uprightness. $\mathrm{Li}$ - indicates etiquettes in personal and institutional life. "According to Confucian theory, only a person who is always a source of love, morally upright and whose behavior not only in personal but also in the institutional life is impeccable, is worthy of being a teacher. An ideal teacher is a guide and source of interest who loves the subject, the profession and last but not the least loves the students. It is very challenging for the $21^{\text {st }}$ century educators to keep up with the changing world unless they are lifelong learners and an effective catalyst to this social and economic change.

Today we are in a technological world where things are happening fast. A question that educators ask themselves is whether they are capable of training the young citizens to be the torch barriers of the noble human world. It is not just enough for the young learners to acquire knowledge to earn a living but also require them to be a good citizen and be educated as a whole child. Changing world at different levels raises a big concern to focus on the relevance and importance of value education at the same time emphasizes on the need to train teachers in new techniques to promote a quality system of education with a focus of value based education.

Before planning an orientation workshop for teachers, it is important first to understand how to construct a values curriculum for quality education. Following are the steps that administrators and curriculum developers can take to structure the value based curriculum:

1. Articulate Vision statements and the underlying principles of value based curriculum

2. Outline values to be integrated in the curriculum

3. Duration and formulation detailed specific objectives and lesson plans for each value according to age and mental maturity.

4. Selection of appropriate activities, seminars, fieldwork, group-work \& projects necessary to achieve the objectives.

5. Integrating values in every subject based on the needs of the individual and society.

6. Organizing these units meaningfully in a coherent simple way

7. Outlining an evaluation plan to assess the manner in which values objective is attained

8. Ongoing scope of open discussion with parents and community about the improvement of the curriculum

9. Modifying and improving the Curriculum based on the above step and finalization. 
10. Planning teacher training workshop and orientation on value based curriculum to promote understanding of the underlying principles and aim to create robust learning environment

After a school has successfully planned a values curriculum, it is very important that the school plans orientation training workshop for teachers to enable them to implement and integrate the curriculum into the class effectively.

\section{Ideas for successful teacher training}

Multiple schools worldwide have introduced Value-Based programs as part of their curriculum. These curriculums are getting very popular in the schools in UK and India, and are getting attention in the schools in USA as part of character education. Training and discussion is needed to understand the underlying principles, aim and approach to value based education. Workshops could provide a platform to teachers to practice teaching an activity that imbibe values as well as give them an opportunity to experience it as a child. Through these trainings teachers can not only understand their own values and strengths but also gain a better understanding of their students.

Values cannot be just taught students but have to be modeled and imbibed by adults and teachers so that they become part of the character of the individual. The values curriculum promotes a learning environment where values are absorbed progressively and through a variety of activities structured according to the relevance and age of the students. The process of learning is based on experiences, action and reflection through projectbased learning, seminars, group-work, dialogue, role-play, films and other media presentations, fieldwork.

Teacher training is needed to help teachers equip with new strategies and techniques to promote values learning. The following components can be included in a 3-5 days workshop for training teachers to integrate values in their classroom and make it an experiential learning:

1. Workshops need to be interactive

2. Discussion on underlying principles, aim and approach to values education with mentors

3. Guide teachers in day to day lessons and transactions. Practice teaching an activity, experience an activity as a student and receive feedback from one another

4. Equip teachers to provide as many real-life situations to imbibe a value. Share creative thoughts among each other

5. Open discussion with teachers on new ideas for improving and evolving the curriculum

Through value oriented teacher education, the challenge of teacher education to prepare teachers to take care of the holistic education of children can be resolved. New courses and professional programs are being developed by several institutions to enable value education to be integrated in the academic curriculum. National Council for Teacher Education (NCTE) is well aware of the challenge in providing value orientation to teacher education and has been conducting orientation programs on education in human values for teacher educators. Titles related to value education available from the NCTE web site are: Education for Character Development; Education for Tomorrow; Report of the Working Group to Review Teachers' Training Programme; Role and Responsibility of Teachers in Building up Modern India; Gandhi on Education; Sri Aurobindo on Education; and Tilak on Education (http://www.ncte-in.org ).

Furthermore, the following approaches can be used for teaching values in character building activities as reported on the UNESCO APIED on Education for Affective Development

1. Telling: A process for developing values that enables a pupil to have a clear picture of a value _ laden situation by means of his own narration of the situation.

2. Inculcating: An approach geared towards instilling and internalizing norms into person's own value systems.

3. Persuading: the process of convincing the learner to accept certain values and behave in accordance with what is acceptable.

4. Modeling: A strategy in which a certain individual perceived as epitomizing desirable/ideal values is presented to the learners as a model.

5. Role playing: Acting out the true feelings of the actor(s) by taking the role of another person but without the risk of reprisals.

6. Simulating: A strategy in which the learners are asked to pretend to be in a certain situation called for by the lesson and then to portray the events and also by imitating the character's personality.

7. Problem solving: An approach wherein a dilemma is presented to the learners asking them what decisions they are going to take.

8. Discussing situations, stories, pictures, etc: This technique asks the learners to deliberate on and explain the details in the lesson.

9. Studying biographies of great men: This is an approach that makes use of the lives of great men as the subject matter for trying to elicit their good needs and thoughts worthy for emulation.

10. Moralizing: The process of working out a sense of morality through active structuring and restructuring of one's social experiences (e.g. moral reasoning and analysis) 
11. Values clarification: Values clarification as a strategy for values development may be considered as learnercentered. It relies heavily on the pupils ability to process his beliefs, behave according to his beliefs and to make a decision whenever confronted with a value dilemma. (As cited in http://www.ncteindia.org/pub/rimse/spk4.htm)

\section{Conclusion}

Values education help students find their place in the world and build their self-confidence. Values in a school curriculum add a dimension to that promote holistic development of the students and benefits their academic achievement. Teachers feel a need to introduce experiential approaches to values education as a means to counter an overly cognitive national curriculum and to address issues of behavior, discipline and social attitudes. The role of teachers cannot be deemed minor in developing good character among students. Values educators must facilitate a student's personal internalized discovery that one would want to be a values-oriented and values-guided person because through such activity one can feel good about oneself, respect oneself, and esteem oneself well (Eidle, 1993). Professional development sessions allowing educators to interact with each other lets individuals examine and view his or her own beliefs differently by using thoughts and testimonies from others; such experiences permit individuals to make sense of the world around them which is transformative learning (Cranton \& King, 2003). There are some training workshops available worldwide for implementing value based education that have tremendously helped teachers develop skills to create a value based environment that promote inspiring and active listening classrooms. Much remains to be done in this direction to make this effort meaningful and worthwhile, keeping in mind what is best for the future.

\section{References}

[1] Arweck, E., Nesbitt, E., \& Jackson, R. 2005. Common values for the common school? Using two values education programmes to promote 'spiritual and moral development'. Journal of Moral Education. 34 (3). 325-342.

[2] Burra, H. 2007. Value Based Education: A Need of Today. Associated Content. Retrieved from http://www.associatedcontent.com/article/355207/value_based_education_a_need_of_today.html?cat=4 .

[3] Cavazos, L., F. 2002. Emphasizing Performance Goals and high-quality education for all students. Phi Delta Kappan. 83 (9).

[4] Cranton, P., \& King, K. P. (2003). Transformative learning as a professional development goal. New Directions for Adult and Continuing Education, 98, 31-37.

[5] Eidle, W., R. 1993. Values education and self-esteem. Education. 113(4).

[6] Lickona, T. (1993). The return of character education. Educational Leadership, 51(3), 6- 11.

[7] Narvaez, D., \& Lapsley, D. K. (2008). Teaching moral character: Two alternatives for teacher education. The Teacher Educator, 43 (2), $156-172$.

[8] National Council for Teacher Education (NCTE). 2013. Retrieved from http://www.ncte-india.org/pub/rimse/rimse.htm

[9] Sanyal, B., C. 2000. Need for value-based education in the twenty-first century. Here-now4u Online Magazine. Retrieved from http://www.here-now4u.de/ENG/need_for_the_value-based_educa.htm 